\title{
Antioxidant Capacity, Physicochemical and Floral Characterization of Honeys from the Northeast of Brazil
}

\author{
de Almeida, A. M. M., Oliveira, M. B. S.; Costa, J. G.; Valentim, I. B.; \\ Goulart, M. O. F.*
}

Rev. Virtual Quim., 2016, 8 (1), 57-77. Data de publicação na Web: 3 de janeiro de 2016

http://rvq.sbq.org.br

\section{Capacidade Antioxidante, Caracterização Físico-química e Floral de Méis do Nordeste do Brasil}

Resumo: O objetivo deste trabalho foi avaliar a origem floral, a qualidade físico-química e a capacidade antioxidante de 15 amostras de mel, da região semi-árida do nordeste do Brasil e correlacionar os dados com a cor e o conteúdo total de fenóis (TPC). Observou-se uma predominância da cor âmbar. A maioria das amostras foi classificada como polifloral e, apenas duas amostras (amarelo claro) foram de origem monofloral. Os valores de TPC variaram de 27,0 a 92,7 mg EAG $100 \mathrm{~g}^{-1}$ de mel, sendo mais elevados em amostras mais escuras. Todas as amostras mostraram capacidade de sequestrar radicais $\mathrm{DPPH}^{\bullet}$ e poder redutor analisado pelos métodos de FRAP e CUPRAC, com melhor desempenho em amostras mais escuras. $\mathrm{O}$ TPC apresenta boa correlação $(p<0,05)$ com os resultados relacionados à capacidade antioxidante. Foram observadas correlações significativas $(p<0,01)$ entre a cor, o TPC $(0,82)$ e também com o poder redutor, via CUPRAC $(0,66)$. A cor mais escura do mel é um indicativo de maior teor de fenóis e maior capacidade antioxidante. As características aqui descritas enriquecem as propriedades de alimento funcional do mel e contribuem para o desenvolvimento da economia regional, fornecendo alternativas para a geração de renda familiar regional.

Palavras-chave: Teor total de fenóis; capacidade antioxidante; análise físico-química; mel.

\begin{abstract}
The aim of this work was to evaluate floral origin, physicochemical quality and antioxidant capacity of 15 honey samples, from a semi-arid region in the northeast of Brazil and to correlate data with color and total phenolic content (TPC). A predominance of amber color was observed. The majority of samples were classified as polifloral and only two samples (the light yellow ones) were monofloral. TPC values ranged from 27.0 to $92.7 \mathrm{mg} \mathrm{GAE} 100 \mathrm{~g}^{-1}$ of honey, being higher in darker samples. All samples had ability to scavenge $\mathrm{DPPH}^{\bullet}$ radicals and showed reducing potential analyzed by FRAP and CUPRAC methods, with the highest performance obtained in darker samples. TPC shows good positive correlations $(p<0.05)$ with the methods used to evaluate antioxidant capacity. Significant correlations $(p<0.01)$ between color and TPC $(0.82)$ and also with reducing power, using CUPRAC (0.66) were observed. The darker color of honey is indicative of higher phenol content and antioxidant capacity. The reported characteristics give an enhanced functional food property to honey and contribute to the development of the regional economy, providing an alternative to family income increase.
\end{abstract}

Keywords: Total phenolic content; antioxidant capacity; physicochemical analysis; honey.

\footnotetext{
* Universidade Federal de Alagoas, Instituto de Química e Biotecnologia, Campus A.C. Simões, Tabuleiro do Martins, 57072-970 Maceió-AL, Brasil.

$M$ mariliaofg@gmail.com DOI: $10.5935 / 1984-6835.20160005$
}

Rev. Virtual Quim. |Vol 8| |No. 1| |57-77| 


\section{Antioxidant Capacity, Physicochemical and Floral Characterization of Honeys from the Northeast of Brazil \\ Alberto Magno M. de Almeida, ${ }^{a, b}$ Mônika B. S. Oliveira, ${ }^{a}$ João G. da Costa, ${ }^{\text {}}$ lara B. Valentim, ${ }^{\text {a,d }}$ Marília O. F. Goulart ${ }^{\mathrm{a}, *}$ \\ a Universidade Federal de Alagoas, Instituto de Química e Biotecnologia, Av. Lourival Melo Mota, s/n, Tabuleiro do Martins, CEP 57072-970, Maceió-AL, Brasil. \\ ${ }^{\mathrm{b}}$ Empresa Baiana de Desenvolvimento Agrícola S.A, Salvador-BA, Brasil. \\ ${ }^{\mathrm{c}}$ Embrapa Tabuleiros Costeiros, Tabuleiro do Martins, CEP 57061-970 Maceió-AL, Brasil. \\ ${ }^{d}$ Instituto Federal de Educação, Ciência e Tecnologia de Alagoas, Campus Maceió-AL, Brasil. \\ * mariliaofg@gmail.com}

Recebido em 3 de janeiro de 2016. Aceito para publicação em 3 de janeiro de 2016

1. Introduction

2. Materials and Methods

2.1. Standards and reagents

2.2. Honey sampling

2.3. Sample floral-type identification

2.4. Physicochemical analysis

2.5. Determination of total phenolic content

2.6. Radical scavenging activity of $\alpha, \alpha$-diphenyl- $\beta$-picrylhydrazyl radical (RSA-DPPH.)

2.7. FRAP assay

2.8. CUPRAC assay

3. Statistical Analysis

4. Results and Discussion

4.1. Sample floral-type identification

4.2. Physicochemical analysis

4.3. Determination of total phenolic content (TPC) and antioxidant capacity

\section{Statistical Results}

6. Conclusions 


\section{Introduction}

Honey is the organic, natural sugar, produced from the nectar and exudation of plant by honey bees. ${ }^{1}$ It is mainly composed by sugars (fructose and glucose), water and also contains small amounts of other constituents like proteins, vitamins, minerals, flavonoids, phenolic acids, enzymes, numerous volatile compounds and other natural products. $^{2-6}$ Among the chemical constituents, it contains a variety of organic compounds with antioxidant and radicalscavenging ability ${ }^{7}$ and contributes to human health and nutrition, being considered a functional food. ${ }^{3,7-12}$

Othman ${ }^{13}$ recently referred to an inverse honey and cancer relationship, showing sizeable evidences that honey is a natural immune booster, anti-inflammatory agent, antimicrobial agent, cancer "vaccine," and promoter for healing chronic ulcers and wounds. It was also reported various possible mechanisms by which honey may inhibit growth and proliferation of tumors or cancers. ${ }^{14}$ Recent data suggest that honey, administered alone or in combination with conventional therapy, might be a novel natural antioxidant in the management of chronic diseases commonly associated with oxidative stress. ${ }^{15}$ On the other hand, honey may have undesirable effects on health. ${ }^{8}$ It can be expected to contain a small number and a limited variety of microorganisms and several heavy metals such as Sb, As, Cd(II), and $\mathrm{Pb}(\mathrm{II})^{8}$ and contaminants, like pesticides and others. Due to that, some precaution must be taken for their use in foods to, also, avoid some problems in persons who suffer from allergy by bee related allergens. ${ }^{8}$

The quality of honey depends upon its physicochemical and sensory properties. ${ }^{16}$ The composition of the different types of honey varies with different floral sources, bee species, as well as climatic and environmental conditions, along with the type of product processing and quality of beekeeper. ${ }^{2,17-19}$ Even if it is made from the same floral origin or the same bee species, honey can vary in texture, color, and composition depending on the geographical origin, soil, weather conditions, and even the age of the bees, which greatly affects the enzymatic activity that produces the honey. ${ }^{20}$ In order to determine the legitimacy of the particular floral source of honey, analysis of pollen (melissopalynology) and either organoleptic or physico-chemical properties are traditionally employed. ${ }^{21}$ Their mineral, trace elements and ash content and electrical conductivity data were repeatedly shown to be a very effective means for the classification purposes of honey of various origins (geographical and botanical). ${ }^{21}$ Reliable techniques for origin authentication are essential because official analysis of honey involves a series of several determinations of chemical and physical parameters that will be of little use for the geographical certification. Therefore, in recent years, several efforts have been made to address authenticity, typicality, traceability and intrinsic quality of honeys with the application of multivariate statistical techniques. ${ }^{21,22}$ Additionally, fluorescence spectroscopy coupled with parallel factor analysis (PARAFAC) and partial least squares discriminant analysis (PLS DA), ${ }^{23}$ along with GC/MS fingerprinting of headspace volatile compounds, subjected to orthogonal partial least squares-discriminant analysis ${ }^{\mathrm{TM}}$ (OPLS $^{\mathrm{TM}}$ DA), soft independent modelling of class analogy (SIMCA), and OPLS ${ }^{\mathrm{TM}}$-hierarchical cluster analysis (OPLS $\left.{ }^{\text {TM }}-\mathrm{HCA}\right),{ }^{24}$ were used for characterization and classification of honey. Low Field (LF) $1 \mathrm{H}$ Nuclear Magnetic Resonance (1H NMR), a rapid method for general application, to investigate water mobility in materials and foods, was used, as well, for differentiating the botanical origin of honeys. ${ }^{25}$ Analytical possibilities of NMR measurements for compositional analysis as well as NMR metabonomics and component profiling for determining the authenticity of honey, along with use of Near Infrared, FTRaman have enriched the arsenal of analytical chemist in this direction. 26,27 Several other methods are available, however, the application of these techniques has to be still developed and systematization 
is necessary and urgent as an important part of authenticity assessments.

The therapeutic value (antibacterial and anti-inflammatory properties) of honey has been partially attributed to its antioxidant properties. ${ }^{3,19,28-31}$ Its nutraceutical and antimicrobial properties against multidrugresistant strains can be also related to the presence of polyphenols. $^{32,33}$ It was reported that the antioxidant capacity depends on the floral source and on seasonal and environmental factors, ${ }^{34-36}$ as well as on the method of processing honey. ${ }^{37}$ Several methods have been applied, in recent years, to evaluate the antioxidant capacity of honey samples. $^{38,39}$

In Brazil, the most common bee is the Africanized bee, which is a hybrid between the African and European Apis mellifera honeybee species. ${ }^{20}$ The cashew honey from Piauí was shown to be dark colored and to have pronounced acidity and a relatively high amount of amino acids, so, the geographical origin of honey is an important parameter in this area of research. ${ }^{40}$ In the semi-arid region of northeast of Brazil, there is a diversified flora. In the Bahia State, many types of farmhouse honey are produced. Bahia honey varieties span a wide range of originating flora and microclimatic and atmospheric conditions. This substantially increases their market value and raises the need to detect potential frauds in origin or even adulteration. $^{21}$

In spite of this, the physicochemical, chemical, and biological properties of honey are still poorly explored. In micro-region of the Ribeira do Pombal (Bahia state from Brazil) composed of 17 municipalities, produced in 2010, 826.74 tons of honey ${ }^{41}$ which correspond to $34.5 \%$ of total production in this state. More than 80 plants were identified as a bee flora, being the Fabaceae family predominant. ${ }^{42}$ As said, honey has antioxidant capacity, however, up to our knowledge, few reports of the antioxidant characteristics of Brazilian honeys, especially from the Northeast of
Brazil has been so far published. Thus, the aim of this work was to evaluate floral origin, physicochemical quality and antioxidant capacity of 15 honey samples and to correlate resulting data with color and the total phenolic content of the samples. The importance of honey has been continuously upgrading because of its nutrient and therapeutic effect, which, in turn is directly related on its phenolic content and antioxidant capacity.

\section{Materials and Methods}

\subsection{Standards and reagents}

Folin-Ciocalteau reagent, ethanol, methanol, $\quad \mathrm{DPPH}^{\bullet} \quad(\alpha, \alpha$-diphenyl- $\beta$ picrylhydrazyl radical) and copper (II) chloride, were purchased from Sigma Aldrich (Steinheim, Germany). Sodium carbonate and gallic acid (GA) were supplied by Vetec Química Fina Ltda (Rio de Janeiro, Brazil) and Trolox was supplied by Merck (Düsseldorf, Germany). All the reagents were of analytical grade and the stock solutions and buffers were prepared with Milli-Q purified water.

\subsection{Honey sampling}

For this study, fifteen honey samples, identified by numbers (1-15) from the Northeast region of Brazil, from Bahia state were analyzed. The samples of honey from Apis mellifera mellifera $\mathrm{L}$. were collected by beekeepers from 7 counties (Table 1 ) within the micro-region Ribeira do Pombal-BA, during January to March, 2011 (period of increased production). All honey samples were processed by centrifugation method and kept at ambient temperature $\left(26 \pm 4{ }^{\circ} \mathrm{C}\right)$, until analysis within two weeks, protocol of storage followed by all beekeepers in the region. 
Table 1. Distribution of the investigated honey samples $(n=15)$

\begin{tabular}{|c|c|c|c|c|}
\hline \multirow[t]{2}{*}{ Localities } & \multicolumn{2}{|c|}{ Coordinates } & \multirow{2}{*}{$\begin{array}{c}\text { Number of } \\
\text { samples }\end{array}$} & \multirow{2}{*}{$\begin{array}{c}\text { Identification of } \\
\text { samples }\end{array}$} \\
\hline & Latitude & Longitude & & \\
\hline Banzaê & $10^{\circ} 35^{\prime} \mathrm{S}$ & $38^{\circ} 37^{\prime} \mathrm{W}$ & 01 & 8 \\
\hline Euclides da Cunha & $10^{\circ} 30^{\prime} \mathrm{S}$ & $39^{\circ} 00^{\prime} \mathrm{W}$ & 03 & 12,13 and 14 \\
\hline Entre Rios & $11^{\circ} 57^{\prime} \mathrm{S}$ & $38^{\circ} 03^{\prime} \mathrm{W}$ & 01 & 15 \\
\hline Heliópolis & $10^{\circ} 41^{\prime} \mathrm{S}$ & $38^{\circ} 17^{\prime} \mathrm{W}$ & 01 & 6 \\
\hline Ribeira do Amparo & $11^{\circ} 02^{\prime} \mathrm{S}$ & $38^{\circ} 26^{\prime} \mathrm{W}$ & 02 & 2 and 3 \\
\hline Ribeira do Pombal & $10^{\circ} 50^{\prime} \mathrm{S}$ & $38^{\circ} 32^{\prime} \mathrm{W}$ & 04 & $1,4,7$ and 10 \\
\hline Tucano & $10^{\circ} 57^{\prime} \mathrm{S}$ & $38^{\circ} 47^{\prime} \mathrm{W}$ & 03 & 5,9 and 11 \\
\hline
\end{tabular}

Source. $^{43}$

\subsection{Sample floral-type identification}

The preparation of honey samples was based on the pollen spectra proposed by Louveaux et al. ${ }^{44}$ Ten grams of honey were dissolved in $20 \mathrm{~mL}$ of distilled water and centrifuged for $5 \mathrm{~min}$ at $3.000 \mathrm{rpm}$. The supernatant was discarded and $2 \mathrm{~mL}$ of glacial acetic acid were added in the test tube and left to stand for $24 \mathrm{~h}$, and again centrifuged and the supernatant discarded. ${ }^{45}$ The sequence analysis was proposed by Erdtman and Nilsson \& Praglowski. ${ }^{46-48}$ About $2 \mathrm{~mL}$ of the acetolysis mixture (9:1) $\left.\left.\left[\left(\mathrm{CH}_{3} \mathrm{CO}_{2}\right) \mathrm{O}\right): \mathrm{H}_{2} \mathrm{SO}_{4}\right)\right]$ were added in tubes that were placed in a water bath $\left(100{ }^{\circ} \mathrm{C}, 5 \mathrm{~min}\right)$, and centrifuged ( $5 \mathrm{~min}, 3.000 \mathrm{rpm}$ ). After this step, $2 \mathrm{~mL}$ of distilled water and one or two drops of ethanol were added, then, the sediment was concentrated by repeated centrifugation. Approximately, $2 \mathrm{~mL}$ of glycerin - water (1:1) were added to the sediment, and then one more centrifugation was performed. The sediment was removed with the aid of a spatula, embedded in a glycerin jelly and deposited on a microscopic slide for subsequent quantitative and qualitative analyses. The examination of the slides was carried out with an optical microscope at $400 x$ in order to identify the pollen types.

\subsection{Physicochemical analysis}

Samples were analyzed for moisture, total acidity, diastase activity, hydroxymethylfurfural (HMF) content, minerals, reducing sugars, apparent sucrose, free acidity, insoluble solids, $\mathrm{pH}$, color and ash. All analyses were performed in triplicate.

The moisture content was determined based on the refractometric method. ${ }^{46}$ All measurements were performed at $20{ }^{\circ} \mathrm{C}$ using an Abbe refractometer (digital refractometer Atago, Germany), after waiting for $6 \mathrm{~min}$ for attaining equilibrium, and obtaining the corresponding \% moisture ( $\mathrm{g}$ $100 \mathrm{~g}^{-1}$ honey) from the refractive index of the honey sample from a standard table (Chataway). ${ }^{47}$

Diastase activity was determined using a buffered solution of soluble starch and honey incubated in a thermostatic bath at $40{ }^{\circ} \mathrm{C} .{ }^{48}$ The diastase value was calculated using the time taken for the absorbance to reach 0.235 , and the results were expressed in Gothe scale. Gothe's scale number is defined as $\mathrm{g}$ starch hydrolysed in $1 \mathrm{~h}$ at $40{ }^{\circ} \mathrm{C}$ per 100 g honey. ${ }^{49,50,51,52}$

Hydroxymethylfurfural (HMF) was determined by standard method. ${ }^{46}$

The ash content was determined by placing $5 \mathrm{~g}$ of honey samples in a crucible in a 
muffle furnace and heating at $600{ }^{\circ} \mathrm{C}$ for $6 \mathrm{~h}$, experiment performed in triplicate with the mean expressed in $\mathrm{g} \% .{ }^{48}$

Reducing sugars and apparent sucrose were determined by titration using the Fehling's test. ${ }^{48,51}$

The $\mathrm{pH}$ values of honey samples $\left(\mathrm{CO}_{2}\right.$ free water) were measured using a pHmeter (Basic 20) and the solution titrated with 0.05 mol L ${ }^{-1}$ sodium hydroxide solution up to $\mathrm{pH}$ 8.3, and free acidity was determined as usual. ${ }^{46}$

Insoluble solids were measured by gravimetric method. ${ }^{47,48}$ The results were

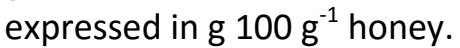

Honey color was determined by measuring the light transmittance of bubbles and debris free honey samples in a colorimeter (Hanna C221, Hungary) using glycerol as a standard. The results were expressed in mm Pfund.

\subsection{Determination of total phenolic content}

The total phenolic content (TPC) from honey samples was determined using FolinCiocalteau (FC) reagent, as described by Cicco et $\mathrm{al}^{53}{ }^{53}$ with the following modifications. Aliquots $(120 \mu \mathrm{L})$ of honey solutions $(2.5 \mathrm{mg}$ $\mathrm{mL}^{-1}$ ) were placed in test tubes and $180 \mu \mathrm{L}$ of water were added. Then, $300 \mu \mathrm{L}$ of FC reagent were added to each tube. After 2 $\mathrm{min}, 2.4 \mathrm{~mL}$ of a $5 \%(\mathrm{w} / \mathrm{v})$ sodium carbonate solution were added. The mixture was shaken and heated at $40{ }^{\circ} \mathrm{C}$ in a water bath for $20 \mathrm{~min}$. The tubes were then cooled rapidly and the developed color was read at $760 \mathrm{~nm}$ in a MultiSpec-1501 UV-Vis spectrophotometer (Shimadzu, Japan). The concentration of phenolic compounds was estimated using a calibration curve traced with gallic acid (GA) in water (4-40 $\left.\mu \mathrm{mol} \mathrm{L}^{-1}\right)$ as a polyphenol reference $(n=3)$. The results are expressed as mg of GA equivalents $100 \mathrm{~g}^{-1}$ of honey (mg GAE $100 \mathrm{~g}^{-1}$ ). The same procedure was performed using $120 \mu \mathrm{L}$ of water as a blank.

\subsection{Radical scavenging activity of $\alpha, \alpha$ - diphenyl- $\beta$-picrylhydrazyl radical (RSA- DPPH.)}

The antioxidant capacity of honeys was measured as their radical scavenging ability (RSA), using the DPPH.method. ${ }^{51,54}$ Thus, 0.30 $\mathrm{mL}$ of honey solution $\left(2.5 \mathrm{mg} \mathrm{mL}^{-1}\right)$ was mixed with $2.7 \mathrm{~mL}$ of DPPH. radical solution $(40 \mu \mathrm{g}$ $\mathrm{mL}^{-1}$ in methanol) in a $3 \mathrm{~mL}$ quartz cuvette. The mixture was homogenized and stored in dark, prior to analysis. The DPPH. absorption values at $516 \mathrm{~nm}$ were recorded at $5 \mathrm{~min}$ intervals for $50 \mathrm{~min}$. The percentage of DPPH radical-scavenging activity (RSA\% - DPPH.) of each sample was calculated as follows: \% RSA $=\left(1-A_{C} / A_{D}\right) \times 100$, where $A_{C}$ is the absorbance of the solution when sample was added at a particular concentration in $30 \mathrm{~min}$, and $A_{D}$ is the absorbance of the DPPH.solution. All the determinations were performed in triplicate. The $\quad I_{50}$ (half maximal inhibitory concentration) was calculated graphically, using a calibration curve in the linear range by plotting the sample concentration versus the corresponding scavenging effect (I\%, inhibition percentage), for $30 \mathrm{~min}$. The value of $1 \%$ was calculated using the equation: $1 \%=$ $\left[\left(\mathrm{Abs}_{0}-\mathrm{Abs}_{1}\right) / \mathrm{Abs}_{0}\right] \times 100$, where $A b s_{0}$ is the absorbance of the control and $A_{b s}$ the absorbance in the presence of the test compound.

\subsection{FRAP assay}

The assay was performed according to the method described by Rufino et al. ${ }^{55}$ which is based on the reduction of a ferric tripyridyltriazine complex to its dark blue ferrous form, in the absence and presence of antioxidants. Briefly, the FRAP reagent is prepared by mixing $2.5 \mathrm{~mL}$ of a solution of 10 $\mathrm{mmol} \mathrm{L}^{-1} \mathrm{TPTZ}$ in $40 \mathrm{mmol} \mathrm{L}^{-1} \mathrm{HCl}$, and adding $2.5 \mathrm{~mL}$ of $20 \mathrm{mmol} \mathrm{L}^{-1} \mathrm{FeCl}_{3}$ and $25 \mathrm{~mL}$ of 0.30 
mol L ${ }^{-1}$ acetate buffer ( $\left.\mathrm{pH} 3.6\right)$, after which, the reagent is heated to $37{ }^{\circ} \mathrm{C}$. Aliquots (90 $\mu \mathrm{L}$ ) of honey solutions $\left(2.5 \mathrm{mg} \mathrm{mL}^{-1}\right)$ were mixed with $270 \mu \mathrm{L}$ of distilled water and 2.7 $\mathrm{mL}$ of FRAP reagent and incubated at $37{ }^{\circ} \mathrm{C}$ for $30 \mathrm{~min}$. The absorbance of the reaction mixture was measured at $595 \mathrm{~nm}$ and a calibration curve was prepared with Trolox (0-30 $\left.\mu \mathrm{mol} \mathrm{L}^{-1}\right)$. The results are expressed as TEAC $_{\text {fRAP }}$, i.e., Trolox Equivalent Antioxidant Capacity, calculated with respect to the original FRAP, in $\mu \mathrm{mol}$ of Trolox $100 \mathrm{~g}^{-1}$ honey.

\subsection{CUPRAC assay}

These assays are based on the reduction of $\mathrm{Cu}(\mathrm{II})$ to $\mathrm{Cu}(\mathrm{I})$ by the combined action of all the antioxidants (reducing agents) in a sample. $1 \mathrm{~mL}$ each of $\mathrm{CuCl}_{2}\left(1 \times 10^{-2} \mathrm{~mol} \mathrm{~L}^{-1}\right)$, neocuproine $\left(7.5 \times 10^{-3} \mathrm{~mol} \mathrm{~L}^{-1}\right)$ and $\mathrm{NH}_{4} \mathrm{Ac}$ buffer solutions $\left(1.0 \mathrm{~mol} \mathrm{~L}^{-1}, \mathrm{pH}\right.$ 7.0) were placed in a test tube. Then, $0.5 \mathrm{~mL}$ of the honey solution (or Trolox ${ }^{\circledR}$, for calibration curve) and $0.6 \mathrm{~mL}$ of $\mathrm{H}_{2} \mathrm{O}$ were added to the initial mixture to reach a final volume of 4.1 $\mathrm{mL}$. The tubes were stoppered, and after $1 \mathrm{~h}$, the absorbance at $450 \mathrm{~nm}$ was recorded against a blank reagent. The calibration curve was prepared with Trolox $^{\circledR}$ (0-73 $\mu \mathrm{mol} \mathrm{\textrm {L } ^ { - }}$ $\left.{ }^{1}\right)^{53,56}$ The results are expressed as TEAC $_{\text {CUPRAC, }}$ in $\mu \mathrm{mol}$ of Trolox ${ }^{\circledR} 100 \mathrm{~g}^{-1}$ of honey.

\section{Statistical Analysis}

All the analyses were carried out in triplicate and the results were reported as mean \pm standard deviation. Analysis of variance and least significant difference tests were conducted to identify differences among means, while a Pearson correlation test was conducted to determine the correlations among means; $p$-value $<0.05$ was regarded as significant. Statistical analysis was performed using SAEG. ${ }^{57}$

\section{Results and Discussion}

\subsection{Sample floral-type identification}

The palynological analysis is very important for the differentiation of honey produced in different geographical and climatic areas. Table 2 lists the percentage of pollen from different plant species in the samples of honey. The characteristics of the melissopalynological analyses confirmed the floral origin of the samples. Among the 15 samples, thirteen were classified as polifloral consisting of a mixture of pollen from different plant species, while samples $\mathbf{8}$ (Pityrocarpa moniliformes (Fabaceae)) and $\mathbf{1 5}$ (Eucalyptus sp. (Mirtaceae)) were monofloral. Monofloral status refers to the presence of a single pollen type in quantities $>45 \%$ of the total pollen in the spectrum. ${ }^{30}$ However, this is not the only parameter. In our work, the monofloral honey was confirmed by observing the high frequency (>45\%) of pollen types associated with the identification of the pollen type of plant species.

The samples were produced in the semiarid region of Bahia state which has a great bee potential due to the diversity of flora. The Myrcia pollen type was found in $93.33 \%$ of the investigated samples and the Eucalyptus pollen type was only present in sample 15. Our results indicated that the distribution of the pollens greatly varies among honey samples confirming the influence of the diversity of the flora of the semi-arid region. According to Barth, ${ }^{58}$ due to the great extension of a country, there is a great variety of honeys, so it is not possible to come to general conclusions. This matter is always of regional concern, with the tendency to address "micro" regions of honey production. 
Table 2. Characterization of the analyzed melissopalynological honey samples

\begin{tabular}{lllll}
\hline Samples & $\begin{array}{l}\text { Type } \\
\text { of honey }\end{array}$ & Pollen type & $\begin{array}{l}\text { Percentage (\%) and } \\
\text { classes'frequency }\end{array}$ & $\begin{array}{l}\text { Quantity of } \\
\text { pollen types }\end{array}$ \\
\hline $\mathbf{0 1}$ & Polifloral & Mimosa tenuiflora & $(32.50 \mathrm{AP} * *)$ & 20 \\
$\mathbf{0 2}$ & Polifloral & Myrcia 1 & $(54.38 \mathrm{DP})$ & 20 \\
$\mathbf{0 3}$ & Polifloral & Myrcia 1 & $(55.00 \mathrm{DP})$ & 9 \\
$\mathbf{0 4}$ & Polifloral & Hyptis multiflora & $(23.7 \mathrm{AP})$ & 20 \\
$\mathbf{0 5}$ & Polifloral & Myrcia 1, Vernonanthura & $(23.01 \mathrm{AP}),(17.57 \mathrm{AP})$ & 19 \\
$\mathbf{0 6}$ & Polifloral & Heliotropium, Salvia & $(25.18 \mathrm{AP}),(24.71 \mathrm{AP})$ & 8 \\
$\mathbf{0 7}$ & Polifloral & Myrcia 1 & $($ (79.57 DP) & 4 \\
$\mathbf{0 8}$ & Monofloral & Pityrocarpa moniliformes (quipé), & $(74.15 \mathrm{DP}),(18.25 \mathrm{AP})$ & 7 \\
& & Piptadenia stipulacea & & \\
$\mathbf{0 9}$ & Polifloral & Myrcia 1, Mimosa tenuiflora & $(25.20 \mathrm{AP}),(20.22 \mathrm{AP})$ & 25 \\
$\mathbf{1 0}$ & Polifloral & Myrcia 1 & $(75.21 \mathrm{DP})$ & 5 \\
$\mathbf{1 1}$ & Polifloral & Myrcia 1, Mimosa tenuiflora & $(25.98 \mathrm{AP}),(19.30 \mathrm{AP})$ & 18 \\
$\mathbf{1 2}$ & Polifloral & Myrcia 1, Gochnatia & $(49.63 \mathrm{AP}),(37.99 \mathrm{AP})$ & 13 \\
$\mathbf{1 3}$ & Polifloral & Gochnatia, Myrcia 1 & (52.17 DP), (42.93 AP) & 7 \\
$\mathbf{1 4}$ & Polifloral & Myrcia 1, Gochnatia & (56.46 DP), (30.93 AP) & 13 \\
$\mathbf{1 5}$ & Monofloral & Eucalyptus, Myrcia 3 & $(68.47 \mathrm{DP}),(26.63 \mathrm{AP})$ & 3 \\
\hline
\end{tabular}

${ }^{*}$ DP, dominant pollen ( $>45 \%$ of total grains)

${ }^{* *}$ AP, accessory pollen (16-45\%)

\subsection{Physicochemical analysis}

Table 3 lists the results obtained for the physicochemical parameters analyzed in the 15 samples of honey. Data show that the studied honey samples are of good quality. The moisture content is one of the main parameters of quality analysis of honey. Moisture is the second component in an amount which varies depending on the climate, floral origin and harvest time. ${ }^{50}$ The moisture content (\%) in the investigated samples ranged from 17.46 to 20.28 , which is within the imposed limit $\leq 20 \% .{ }^{49,50}$ Higher contents can lead to honey fermentation during storage. The results are similar to other studies. ${ }^{30,59,60}$ Ash content is within the maximum limit of $0.6 \%$. Concerning the total reducing sugars, all samples varied from 74.54 to $83.93 \%$. These values were similar to the 70.38 to $87.39 \%$ obtained in honey samples from Piauí, ${ }^{61,62}$ north of Brazil. As such, all samples were above the $65 \%$ lowest limit allowed in Brazil. ${ }^{50}$ Apparent sucrose (maximum limit of $6 \%$ ), insoluble solids

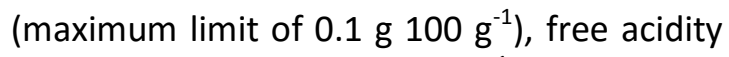
(maximum limit of $50 \mathrm{mEq} \mathrm{kg}{ }^{-1}$ ) values were 12.77 to $55.72\left(\mathrm{mEq} \mathrm{kg}^{-1}\right)$, similar to the ones (30.4 to 58.4) reported in samples of Spanish honey. ${ }^{63}$ Despite not being required by Brazilian legislation, ${ }^{50}$ for $\mathrm{pH}$ (range of 3.20 to 4.60), the values were within the allowed Brazilian standards, like in honey from cashew flowers, around, 3.67. ${ }^{40}$

The content of HMF in honeys is indicative of freshness of honey samples. ${ }^{30}$ Values of HMF ranged from 2.40 to $37.87 \mathrm{mg} \mathrm{kg}^{-1}$, while the allowed limit is $60 \mathrm{mg} \mathrm{kg}{ }^{-1}$. ${ }^{50}$ These results were similar to other studies, for instance, for cashew flowers, from Ceará State, ${ }^{40}$ with values around 14, for Algerian honeys, ${ }^{64}$ which values vary from 15.23 up to $24.21 \mathrm{mg} \mathrm{kg}^{-1}$. It is well known that heating of honey results in the formation of HMF, which is produced during acid-catalyzed dehydration of hexoses, e.g. fructose and glucose. ${ }^{65}$ In Malaysian honey samples, ${ }^{4} \mathrm{HMF}$ concentrations in fresh samples (stored within six months around $25-30{ }^{\circ} \mathrm{C}$ ) varied from 2.80 to $24.87 \mathrm{mg} \mathrm{kg}^{-1}$, i.e., within the 
internationally recommended range $(80 \mathrm{mg}$ $\mathrm{kg}^{-1}$ for tropical honeys). However, the same honey samples, when stored from 12 to 24 months, were shown to have much higher
HMF concentrations, ranging from 118.47 up to $1139.95 \mathrm{mg} \mathrm{kg}^{-1}$, which indicate that the shelf validity (at room temperature) is limited. ${ }^{66}$

Table 3. Physicochemical parameters of honey

\begin{tabular}{c|c|c|c|c|c|c|c|c|c|c}
\hline $\begin{array}{c}\text { Honey } \\
\text { sample }\end{array}$ & $\begin{array}{c}\mathrm{HMF} \\
(\mathrm{mg} \\
\left.\mathrm{kg}^{-1}\right)\end{array}$ & $\begin{array}{c}\text { Moisture } \\
\text { content } \\
(\%)\end{array}$ & $\begin{array}{c}\text { Minerals } \\
(\%)\end{array}$ & $\begin{array}{c}\text { Reducing } \\
\text { sugars (\%) }\end{array}$ & $\begin{array}{c}\text { Apparent } \\
\text { sucrose (\%) }\end{array}$ & $\begin{array}{c}\text { Diastase } \\
\text { activity } \\
(\text { Gothe) }\end{array}$ & $\begin{array}{c}\text { Free } \\
\text { acidity } \\
(\mathrm{mEq} \\
\left.\mathrm{kg}^{-1}\right)\end{array}$ & $\begin{array}{c}\text { Insoluble } \\
\text { solids (g } \\
\left.100 \mathrm{~g}^{-1}\right)\end{array}$ & $\begin{array}{c}\text { pH } \\
\text { Color } \\
\text { pfund) }\end{array}$ \\
\hline $\mathbf{1}$ & 37.87 & 18.50 & 0.248 & 75.66 & 1.41 & 21.66 & 45.4 & 0.019 & 3.72 & 91 \\
\hline $\mathbf{2}$ & 10.55 & 20.28 & 0.27 & 75.08 & 0.51 & 24.28 & 40.22 & 0.025 & 4.17 & 150 \\
\hline $\mathbf{3}$ & 15.49 & 19.07 & 0.237 & 79.44 & 1.92 & 12.09 & 40.56 & 0.067 & 4.10 & 135 \\
\hline $\mathbf{4}$ & 19.23 & 18.61 & 0.274 & 77.52 & 1.06 & 19.98 & 45.22 & 0.025 & 3.90 & 91 \\
\hline $\mathbf{5}$ & 6.89 & 18.86 & 0.472 & 74.54 & 0.98 & 25.58 & 34.06 & 0.022 & 4.14 & 102 \\
\hline $\mathbf{6}$ & 29.18 & 17.85 & 0.19 & 75.49 & 1.34 & 23.66 & 37.67 & 0.016 & 3.89 & 74 \\
\hline $\mathbf{7}$ & 16.91 & 19.14 & 0.264 & 75.59 & 2.63 & 22.76 & 38.01 & 0.019 & 3.75 & 87 \\
\hline $\mathbf{8}$ & 4.34 & 17.93 & 0.075 & 76.77 & 2.55 & 8.83 & 12.77 & 0.014 & 3.8 & 12 \\
\hline $\mathbf{9}$ & 27.47 & 18.36 & 0.219 & 78.32 & 1.70 & 4.52 & 38.19 & 0.023 & 3.78 & 81 \\
\hline $\mathbf{1 0}$ & 23.73 & 18.89 & 0.188 & 77.26 & 2.42 & 14.44 & 36.5 & 0.018 & 3.83 & 96 \\
\hline $\mathbf{1 1}$ & 12.95 & 18.67 & 0.225 & 78.89 & 2.9 & 22.12 & 40.46 & 0.003 & 3.98 & 116 \\
\hline $\mathbf{1 2}$ & 27.09 & 18.24 & 0.305 & 78.98 & 2.49 & 0.13 & 48.04 & 0.007 & 3.72 & 72 \\
\hline $\mathbf{1 3}$ & 2.99 & 18.55 & 0.309 & 79.81 & 1.5 & 0.14 & 55.72 & 0.011 & 3.65 & 73 \\
\hline $\mathbf{1 4}$ & 32.33 & 17.46 & 0.246 & 83.93 & 1.79 & $\mathrm{ND}$ & 47.99 & 0.010 & 3.69 & 72 \\
\hline $\mathbf{1 5}$ & 2.40 & 17.47 & 0.293 & 79.60 & 1.76 & 11.57 & 14.57 & 0.011 & 4.25 & 34 \\
\hline
\end{tabular}

The diastase activity is a parameter related to the maturity and freshness of honey and diastase ( $\alpha$-amylase) is an enzyme present in honey ${ }^{67}$ Honey samples exhibited very different values, ranging from 0.13 up to 25.58 in Gothe scale. Only four samples (9, 12, 13 and 14) presented an inappropriate diastase activity ( $<8$ in Gothe scale). Ozcan, ${ }^{17}$ suggested that the enzyme activity below this limit can be explained by a variety of reasons, including the amount of sucrose in food source, rate of nectar flow and even age of the bees. Different values were found in several regions. In Turkey honeys, ${ }^{68}$ variations from 3 to 70.4 were found, while in Silva et al., ${ }^{34}$ in honey samples from Portugal, the values ranged from 3 to 38, in Gothe scale.

In Brazil, the diastase activity should be at least 8 on a Gothe scale. Honeys, with low enzyme content, should have at least a diastase activity corresponding to three ranges of Gothe, while HMF content does not exceed $15 \mathrm{mg} \mathrm{kg}^{-1}$. 50

The color of honey is one of the main sensory characteristics, with great attractiveness for consumers. It depends on various factors, such as their mineral content, ${ }^{69}$ pigment content (carotenoids and flavonoids), ${ }^{70}$ botanical origin, suspended particles as pollen. ${ }^{71}$ It can also be affected by heat, as an increase in temperature catalyses melanoidin formation and caramelisation reactions, time of storage, and antioxidant activity. ${ }^{20}$ Phenolic compounds can greatly contribute to the colour, especially when complexed to metals, notably iron. ${ }^{20}$ The results of color analyzes of the honey samples revealed a percentage of $33 \%$ for each amber and light amber and $20 \%$ for dark amber, while for extra white and white, $7 \%$ of 
each was found. Thus, there is a predominance of amber color in the present case. Lacerda, ${ }^{72}$ analyzed 24 samples of honey from Vitoria da Conquista-BA and found a predominance of white (29\%) and dark amber (25\%). It is interesting to note that samples $\mathbf{8}$ and $\mathbf{1 5}$ are the lightest (Table 3 ) and they were classified as monofloral. In Sant'Ana et al., ${ }^{20}$ colour was also classified according to visual analysis and Pfund scale. They analyzed 60 Brazilian Apis mellifera honeys from different floral origins and obtained from different parts of the state of Rio de Janeiro. Most of the honeys were considered to be amber or dark amber by the Pfund classification. González-Miret et al. ${ }^{73}$ showed that light coloured honeys generally have less than $2.79 \mathrm{mg} / \mathrm{kg}$ of iron, while amber honeys have an average of $2.84 \mathrm{mg} / \mathrm{kg}$ and dark coloured honeys have more than $4.26 \mathrm{mg} / \mathrm{kg}$.

\subsection{Determination of total phenolic content (TPC) and antioxidant capacity}

Several studies have linked the presence and amount of polyphenols with nutrition and human health. ${ }^{3,7-12,19,28-39}$ Table 4 shows TPC, DPPH, FRAP and CUPRAC results obtained from 15 honey samples. The TPC values ranged from 27.0 to $92.7 \mathrm{mg} G A E$ $100 \mathrm{~g}^{-1}$ of honey, being the highest values found for samples 2, $\mathbf{5}$ and $\mathbf{1 1}$ (all classified as polifloral honeys), when compared to samples 8 and $\mathbf{1 5}$ (monofloral honeys). Variations in TPC may be due to different floral origins. These results were similar to other studies reported in literature (Table 5).
All samples have radical scavenging ability (Table 4 and Fig. 1), with a consumption of DPPH ranging from $7.3 \%$ to $25.9 \%$, in $30 \mathrm{~min}$, compared to standard gallic acid, consuming $100 \%$ of the radical.

It should be emphasized that the comparison on antioxidant capacity among honeys is, in large extension, difficult, due to the use of different protocols, standards and unities used. Systematization is urgently required. The values diverge too much (Table 5), depending on several factors, as mentioned before. Al et al., ${ }^{74}$ for Romanian honeys, found RSA values from $35.8 \%$ to $49.1 \%$ while, Baltrusaityte et $a{ }^{2}{ }^{28}$ for Lithuanian honeys, obtained variations from $36.5 \%$ to $86.90 \%$. In our work, $I_{50}$ values of honey samples varied from 8.2 to $14.5 \mu \mathrm{g} \mathrm{m}$ ${ }^{1}$ (Table 4), comparable to those reported in the literature (Table 5), mainly from tropical regions, like the ones from Roraima and Malaysia.

The reducing capacity of the samples was evaluated by FRAP and CUPRAC methods (Table 4, Fig. 1). The FRAP values varied from 99.4 to $720.4 \mu \mathrm{mol}$ TEAC $100 \mathrm{~g}^{-1}$ honey and for CUPRAC between 338.7 to $960.0 \mu \mathrm{mol}$ TEAC $100 \mathrm{~g}^{-1}$. The lowest reducing capacity was obtained for sample $\mathbf{8}$ for both methods. The highest FRAP value was obtained for samples 13 followed by 14 and 12 . For CUPRAC, the highest capacity was obtained for samples 2-3 and 13-14 (Fig. 1). All samples have reducing capacity, with emphasis on samples collected in the municipalities of Ribeira do Amparo (samples 2 and 3) and Euclides da Cunha (12, 13 and 14), where there is a predominant semi-arid vegetation. 
Table 4. TPC, DPPH, FRAP and CUPRAC of honey samples

\begin{tabular}{|c|c|c|c|c|c|}
\hline \multirow[b]{2}{*}{$\begin{array}{l}\text { Honey } \\
\text { Sample }\end{array}$} & \multirow{2}{*}{$\begin{array}{c}\text { TPC } \\
\begin{array}{c}\text { mg GAE } \\
\text { of honey }\end{array}\end{array}$} & \multicolumn{2}{|c|}{$\mathrm{DPPH}^{\circ}$} & \multirow{2}{*}{$\begin{array}{c}\text { FRAP } \\
\text { TEAC*** }_{\text {FRAP }} \\
\left(\mu \mathrm{mol} \text { TE } 100 \mathrm{~g}^{-1}\right)\end{array}$} & \multirow{2}{*}{$\begin{array}{c}\text { CUPRAC } \\
\text { TEAC }^{* * *}{ }_{\text {CUPRAC }} \\
\left(\mu \mathrm{mol} \text { TE } 100 \mathrm{~g}^{-1}\right)\end{array}$} \\
\hline & & RSA\% ** & $\begin{array}{c}\mathrm{IC}_{50} \\
\left(\mathrm{mg} \mathrm{mL}^{-1}\right)\end{array}$ & & \\
\hline 1 & $41.1 \pm 3.5 \mathrm{~h}$ & $16.7 \pm 0.7 \mathrm{e}$ & - & $241.6 \pm 4.8 \mathrm{~h}$ & $556.3 \pm 22.2 f$ \\
\hline 2 & $81.5 \pm 2.1 c$ & $20.5 \pm 0.9 d$ & $8.2 \pm 1.3$ & $563.7 \pm 37.0 \mathrm{c}$ & $960.1 \pm 11.0 \mathrm{a}$ \\
\hline 3 & $76.0 \pm 0.9 d$ & $23.3 \pm 0.8 b$ & $12.1 \pm 0.2$ & $513.3 \pm 23.1 d$ & $926.2 \pm 9.7 \mathrm{a}$ \\
\hline 4 & $74.0 \pm 3.6 \mathrm{~d}$ & $7.3 \pm 1.2 \mathrm{i}$ & - & $302.4 \pm 3.4 \mathrm{~g}$ & $619.8 \pm 15.9$ e \\
\hline 5 & $83.0 \pm 1.3 b$ & $15.0 \pm 0.9 \mathrm{~g}$ & $14.4 \pm 0.1$ & $325.5 \pm 7.2 f$ & $595.1 \pm 6.2 \mathrm{f}$ \\
\hline 6 & $43.0 \pm 4.4 \mathrm{~g}$ & $17.0 \pm 0.3 \mathrm{e}$ & - & $165.1 \pm 17.3 \mathrm{i}$ & $462.1 \pm 17.4 \mathrm{~g}$ \\
\hline 7 & $40.0 \pm 2.1 \mathrm{~h}$ & $15.6 \pm 0.0 f$ & - & $195.2 \pm 8.5 \mathrm{i}$ & $453.0 \pm 3.8 \mathrm{~g}$ \\
\hline 8 & $27.0 \pm 2.3 \mathrm{i}$ & $13.1 \pm 0.7 \mathrm{~h}$ & - & $99.4 \pm 3.8 \mathrm{j}$ & $338.7 \pm 8.45 h$ \\
\hline 9 & $51.0 \pm 0.8 f$ & $20.6 \pm 0.6 d$ & $12.9 \pm 0.04$ & $518.0 \pm 10.7 d$ & $628.5 \pm 11.5 \mathrm{e}$ \\
\hline 10 & $57.0 \pm 1.9 \mathrm{e}$ & $18.9 \pm 0.1 d$ & $14.5 \pm 0.03$ & $392.1 \pm 8.6 \mathrm{e}$ & $578.1 \pm 32.4 \mathrm{f}$ \\
\hline 11 & $92.7 \pm 2.1 \mathrm{a}$ & $21.4 \pm 1.7 \mathrm{c}$ & $14.4 \pm 0.06$ & $347.9 \pm 8.4 f$ & $672.9 \pm 17.1 d$ \\
\hline 12 & $51.0 \pm 1.4 \mathrm{f}$ & $20.1 \pm 0.8 d$ & $12.0 \pm 0.05$ & $597.6 \pm 19.9 b$ & $730.6 \pm 42.5 c$ \\
\hline 13 & $46.0 \pm 3.4 \mathrm{~g}$ & $25.9 \pm 0.2 \mathrm{a}$ & $13.7 \pm 0.07$ & $720.4 \pm 23.8 \mathrm{a}$ & 793. $2 \pm 13.7 b$ \\
\hline 14 & $51.0 \pm 0.4 \mathrm{f}$ & $22.4 \pm 0.9 c$ & $12.5 \pm 0.07$ & $603.6 \pm 15.4 b$ & $796.9 \pm 46.8 b$ \\
\hline 15 & $31.0 \pm 1.3 \mathrm{i}$ & $17.1 \pm 0.9 \mathrm{e}$ & - & $181.4 \pm 21.6 i$ & $592.8 \pm 17.2 \mathrm{f}$ \\
\hline
\end{tabular}

*Gallic Acid Equivalents. ** Percentage of DPPH radical-scavenging ability in $30 \mathrm{~min}$. $* * *$ TEAC: Trolox Equivalent Antioxidant Capacity ( $\mu$ mol TEAC $100 \mathrm{~g}^{-1}$ honey). ${ }^{1}$ Values are mean \pm SD. Means with different letters within a column are significantly different $(p<0.05)$.

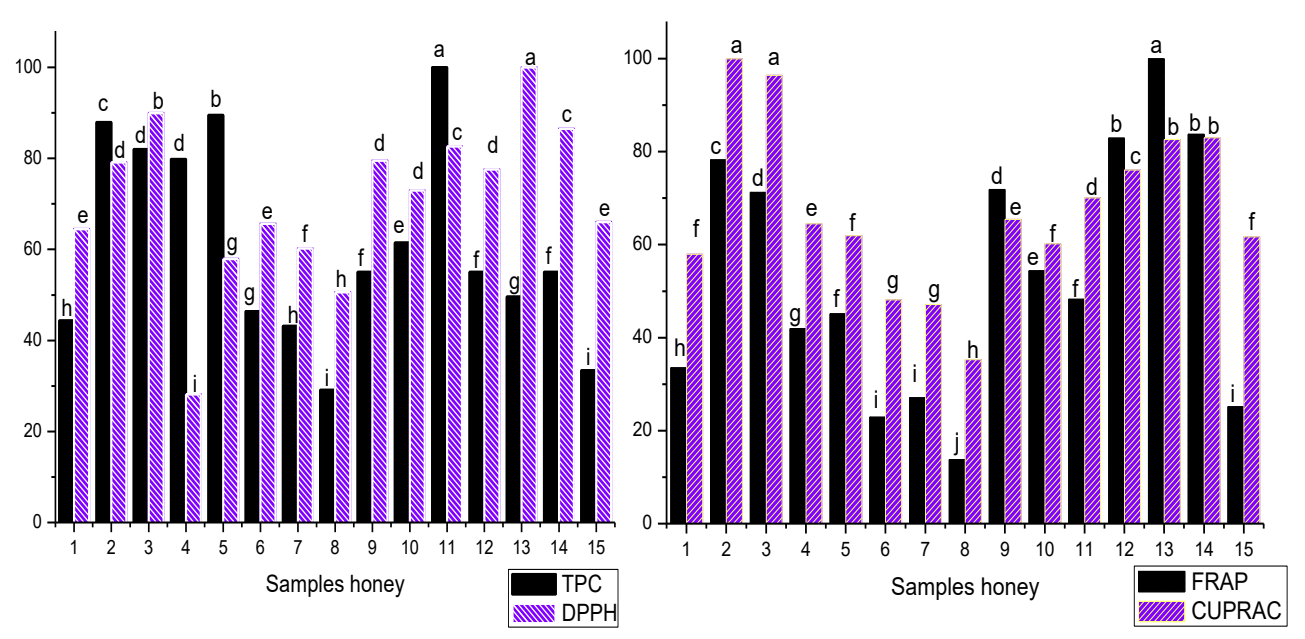

Figure 1. Normalized parameters of the honey samples, in relation to each antioxidant test. The number of the sample is located between the values of TPC and DPPH or between TRAP and CUPRAC. The highest activity was considered $100 \%$ and the other values correspond to a relative percent of activity. Within each column, averages denoted with the same letter were not significantly different by this test $(p<0.05)$ 
Table 5. Comparative results of TPC and DPPH among honeys from different parts of the world

\begin{tabular}{|c|c|c|c|}
\hline Localities & $\begin{array}{c}\text { TPC } \\
\text { (mg *EAG/ } 100 \mathrm{~g} \text { of honey) } \\
\text { (variation) }\end{array}$ & $\begin{array}{c}\text { DPPH } \\
\text { IC }_{50}\left(\mathrm{mg} \mathrm{mL}^{-1}\right) \text { or } \\
\% \text { inhibition } \\
\text { (variation) }\end{array}$ & References \\
\hline Brazil & $27.02 \pm 2.3$ to $92.70 \pm 2.1$ & $\begin{array}{c}8.2 \pm 1.3 \text { to } 14.5 \pm 0.03 \\
(7.3 \% \text { to } 25.9 \%)\end{array}$ & Present work \\
\hline Romenia & $2.00-125$ & $40.67 \%-64.83 \%$ & 74 \\
\hline Brazil & $34.0 \pm 1.8$ to $78.2 \pm 2.7$ & $\begin{array}{c}10.81 \pm 0.50 \text { to } 52.64 \pm \\
4.70\end{array}$ & 75 \\
\hline Brazil & $\begin{array}{c}61.11 \pm 0.07 \text { to } 141.06 \pm \\
0.31\end{array}$ & $\begin{array}{c}10.19 \pm 1.65 \text { to } 83.01 \pm \\
1.46\end{array}$ & 76 \\
\hline $\begin{array}{c}\text { Brazil (Rio de Janeiro, SE } \\
\text { Brazil) }\end{array}$ & $\begin{array}{c}95.88 \pm 16.92 \text { to } 115.14 \pm \\
20.13\end{array}$ & $\begin{array}{c}16.95 \pm 7.28 \text { to } 25.02 \pm \\
9.37\end{array}$ & 20 \\
\hline Brazil (Roraima) & $25.0 \pm 3.24$ to $54.8 \pm 3.00$ & 3.17 to 8.79 & 77 \\
\hline Italy & 17.1 to 60.0 & 5.0 to 15.5 & 78 \\
\hline Italy & $11.08 \pm 2.80$ to $14.26 \pm 4.14$ & $\begin{array}{c}55.06 \pm 7.04 \% \text { to } 75.37 \\
\pm 7.87 \%\end{array}$ & 79 \\
\hline Italy & $6.6 \pm 0.7$ to $38.9 \pm 7.9$ & 7.08 to 64.09 & 80 \\
\hline Italy & $15.13 \pm 3.93$ to $82.49 \pm 4.05$ & $\begin{array}{c}11.39 \pm 2.11 \text { to } 64.33 \pm \\
2.76\end{array}$ & 81 \\
\hline Italy & $6.05 \pm 3.63$ to $27.60 \pm 13.80$ & $\begin{array}{c}7.08 \pm 0.35 \text { to } 64.09 \pm \\
2.56\end{array}$ & 82 \\
\hline Africa & $5.25 \pm 1.5$ to $78.96 \pm 13.8$ & $\begin{array}{c}1.63 \pm 0.17 \text { to } 47.62 \pm \\
0.39\end{array}$ & 83 \\
\hline Africa & $32.6 \pm 0.48$ to $114.8 \pm 1.30$ & $\begin{array}{c}1.37 \pm 0.03 \text { to } 29.13 \pm \\
1.5\end{array}$ & 84 \\
\hline Slovenia & $4.48 \pm 14.8$ to $24.14 \pm 39.5$ & $7.2 \pm 1.2$ to $53.8 \pm 8.5$ & 85 \\
\hline Malaysia & $1.52 \pm 0.51$ to $5.26 \pm 1.21$ & $\begin{array}{c}4.71 \pm 0.36 \text { to } 18.58 \pm \\
0.80\end{array}$ & 4 \\
\hline Malaysia (Tualang) & 27.75 to 83.96 & 5.80 to 10.86 & 86 \\
\hline Poland & $44.3 \pm 5.17$ to $177 \pm 79.4$ & $\begin{array}{c}47.2 \pm 8.75 \text { to } 83.4 \pm \\
4.11\end{array}$ & 87 \\
\hline Poland & $14.28 \pm 16.0$ to $111.3 \pm 52.0$ & _ & 88 \\
\hline Argentina & 18.73 to 107.32 & - & 89 \\
\hline Portugal & $13.22 \pm 0.05$ to $72.78 \pm 0.23$ & $\begin{array}{c}84.98 \pm 1 . \overline{19} \text { to } 168.94 \\
\pm 19.20\end{array}$ & 90 \\
\hline Portugal & $\begin{array}{c}31.85 \pm 2.21 \text { to } 117.65 \pm \\
2.21\end{array}$ & - & 91 \\
\hline Pakistan & $\begin{array}{c}36.01 \pm 0.22 \text { to } 252.00 \pm \\
1.61\end{array}$ & $\begin{array}{c}30.52 \pm 0.31 \text { to } 77.43 \pm \\
0.77\end{array}$ & 92 \\
\hline Serbia & 30 to 139 & (1.31\% to $25.61 \%)$ & 93 \\
\hline Serbia & $9.4 \pm 3.1$ to $62.07 \pm 0.8$ & $\begin{array}{c}(0.22 \pm 0.01 \text { to } 1.21 \pm \\
0.02 \mu \mathrm{mol} \mathrm{TE} / \mathrm{g})\end{array}$ & 94 \\
\hline Venezuela & $38.15-182.10$ & - & 95 \\
\hline India & $47 \pm 0.2$ to $98 \pm 1.2$ & (44\% to $71 \%)$ & 96 \\
\hline Czech Republic & $8.63 \pm 0.20$ to $24.25 \pm 0.06$ & $\begin{array}{c}9.87 \text { to } 44.20 \mathrm{mg} \\
\text { EAscorbic Acid } \\
\left.100 \mathrm{~g}^{-1}\right)\end{array}$ & 97 \\
\hline
\end{tabular}


The samples were grouped according to the following dendrogram (Fig. 2). It is noted that the 15 samples were divided into five groups: one group with 2 samples ( $\mathbf{2}$ and $\mathbf{3}$ ), group 2 with 4 samples $(9,12,13$ and 14$)$, group 3 with 3 samples $(\mathbf{1}, \mathbf{6}$, and $\mathbf{7})$, group 4 with 2 samples (8 and 15$)$ and the fourth group with 4 samples $(\mathbf{4}, \mathbf{5}, 11$ and $\mathbf{1 0})$. The proximity of the samples suggests similar physical and chemical characteristics, such as those present in the samples within each group formed. Moreover, the distances between the samples show physicochemical differences between them, such as those between groups.

Cluster analysis has been used by Moreti, ${ }^{98}$ to study honey samples of the State of Ceará, and Sodré, ${ }^{61}$ in honey samples of Piauí State, helping to verify that the samples of the same floral origin were grouped in the same groups or subgroups.

In this work, it appears that in group 1, samples from the same source, county of Riverside Support samples, were grouped. Samples $\mathbf{2}$ and $\mathbf{3}$ have, in common, darker colors, in $\mathrm{pH}$ values above 4.1 , acidity greater than $40 \mathrm{mEq} \mathrm{kg}{ }^{-1}$, high content of total phenols, high antioxidant capacity, statistically superior antioxidant capacity through analysis by FRAP method. It is observed that the samples, classified as monofloral, were grouped into the same group 4 with two samples ( 8 and 15 ). They have in common, a lighter color and lower antioxidant activity. In Group 5, the samples from the same locality, the municipality of Euclides da Cunha, which has a savanna vegetation, have in common, high antioxidant activity, low diastatic activity and are polifloral.

Euclidian distance

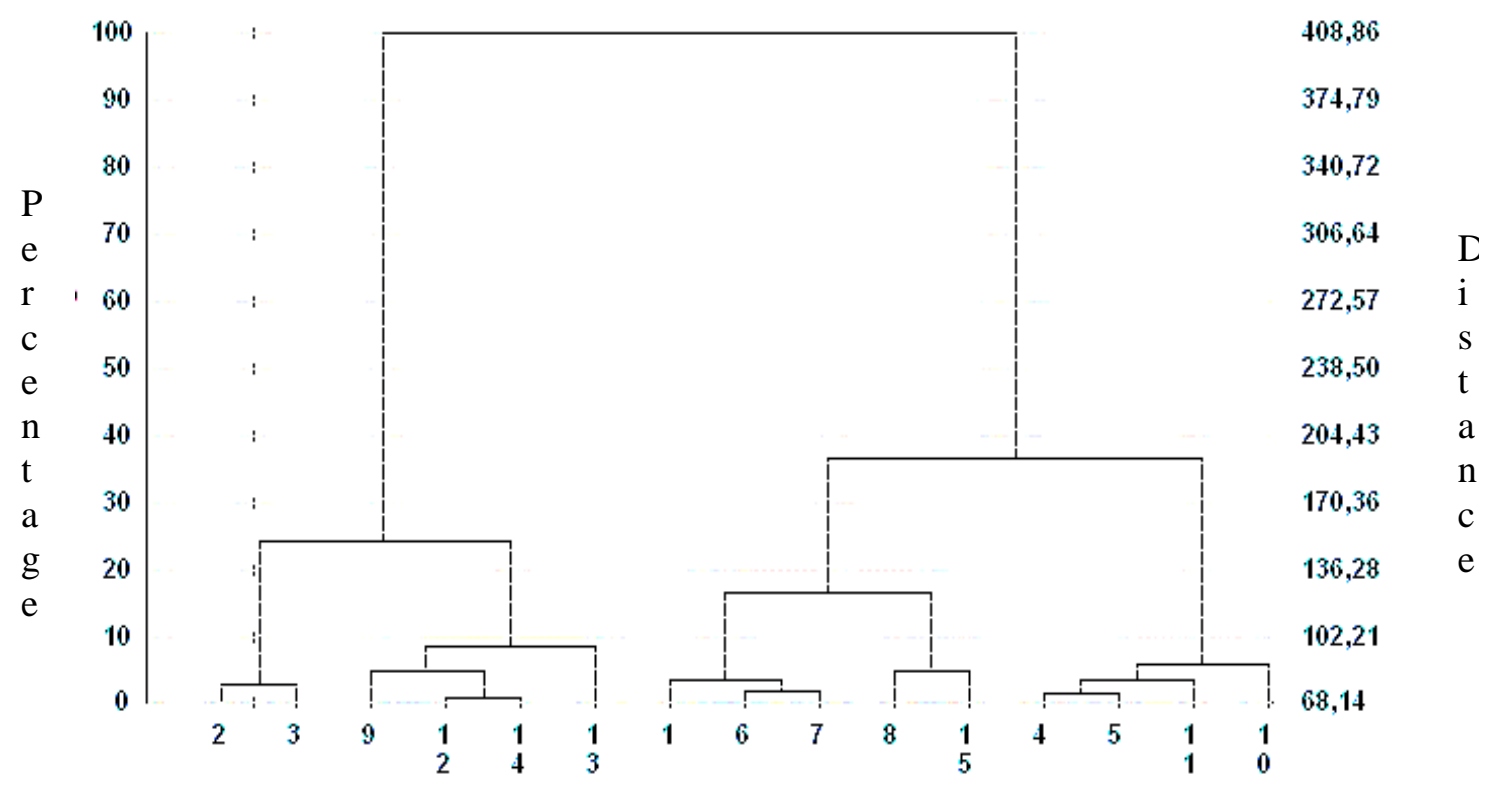

Honey Samples

Figure 2. Dendrogram of the cluster analysis using the average Euclidean distance and UPGMA for 15 samples of honey produced by Apis mellifera in the northeastern state of Bahia, in relation to physicochemical characteristics. Group 1 has two samples (2 and 3); group 2, 4 samples (9,12,14 and $\mathbf{1 3})$; group 3,3 samples $(\mathbf{1}, \mathbf{6 , 7})$; group 4,2 samples ( $\mathbf{8}$ and $\mathbf{1 5})$ and finally group 6 , with 4 samples $(\mathbf{4 , 5 , 1 1}$ and $\mathbf{1 0})$ 


\section{Statistical Results}

The analysis of variance and least significant difference tests showed statistically significant differences among the samples for the different methods (Table 4 and Fig. 1). These results had shown that sample 11 was the best for TPC, the sample 13, in DPPH and FRAP assays and samples 2 and 3, for CUPRAC. The correlation among TPC, DPPH, FRAP and CUPRAC and between these with color in honey samples were established. A statistically significant correlation $(p<0.05)$ was observed between TPC with CUPRAC (0.55), DPPH with FRAP (0.73) and CUPRAC (0.64), FRAP with CUPRAC (0.83). This suggests that all assays are recommendable for evaluating antioxidant capacity in honey samples. Also, the correlations between the color with TPC, DPPH, FRAP and CUPRAC were performed. The color showed significant correlation $(p<0.01)$ with TPC (0.82) and CUPRAC (0.66). Interestingly, the lighter honey samples (8 and 15) had the lowest TPC values, while samples classified as dark amber $(\mathbf{2}, \mathbf{3}$ and $\mathbf{1 1})$ presented the highest TPC, suggesting the influence of polyphenols on honey color. The existence of positive correlations between the color of honeys and their antioxidant properties has been demonstrated. ${ }^{6,20,29,39,99,100}$

In Santana et al., ${ }^{20}$ linear relationships were observed between colour and flavonoid content, total phenolics and antioxidant capacity, and total flavonoid and phenolic contents. The white-coloured Citrus honey showed the lowest antioxidant activity, while the light ambar Verbenaceae honey showed the highest total phenolics and antioxidant activity. Dark-coloured and polyfloral honeys, though less popularized among consumers, showed average to high antioxidant capacity. ${ }^{20}$ In Polish honeys, ${ }^{88}$ the honeys' color ranged from pale yellow to dark amber. Dark buckwheat honey with much higher phenolic content (111.30 mg GAE/100 g) exhibited higher antioxidant activity.
The correlation obtained between the antioxidant capacity and the total polyphenolic content suggests that the phenolic compounds are, in great part, responsible for the antioxidant effects of honey ${ }^{99,100}$ These results suggest that honey may be used as a healthy alternative to sugar in many products and thereby serves as a source of dietary antioxidants. Honey with high levels of antioxidants can provide protection to healthy human subjects. ${ }^{101}$

\section{Conclusions}

The present study showed that honey samples from the micro-region of Ribeira do Pombal (Bahia state, Brazil) have good antioxidant potential. Among the 15 honey samples, 13 were classified as polifloral consisting of a mixture of pollens from different plant species, while samples $\mathbf{8}$ (Pityrocarpa moniliformes (Fabaceae)) and $\mathbf{1 5}$ (Eucalyptus sp. (Mirtaceae)) were monofloral honeys. The Myrcia pollen type was found in $93.33 \%$ of the investigated samples and the Eucalyptus pollen type was only present in sample 15. Our results indicated that the distribution of the pollens greatly varies among honey samples confirming the influence of the diversity of the flora of the semi-arid region. Physicochemical parameters are within the allowed standards established by Brazilian law. Only four samples (9, 12, 13 and 14) presented an inappropriate diastase activity. There is a predominance of amber color for samples. Honey samples with dark amber and amber colors present higher antioxidant capacity than light color honeys. Also, these honeys were classified as polifloral. All samples presented good total phenolic content and antioxidant capacities, being the highest performance obtained for the darker and polifloral ones. Positive correlations were found among total phenolic content, antioxidant capacities and color. The increase of the color intensity seems to be related to increase on the concentration of 
polyphenols.. The importance of honey has been continuously upgrading because of its nutrient and therapeutic effect, which, in turn is directly related on its phenolic content and antioxidant capacity. These properties should be publicized to increase comsumption among the population. It is important to emphasize that the honey produced in the microregion Ribeira do Pombal contributes to the development of regional economy and provide an alternative to family income increase.

\section{Acknowledgements}

The authors gratefully acknowledge the financial support of the Brazilian research funding agencies CAPES/PNPD, CAPES/PROCAD/NF, INCT-Bioanalítica and PRONEX/ FAPEAL.

\section{References}

${ }^{1}$ Sataruba, R.; Subha, G. Physical, chemical and antioxidant properties of honey: $A$ review. Asian Journal Chemical Pharmaceutical Research. 2014, 2, 96. [Link]

${ }^{2}$ Kuçuk, M.; Kolayli, S.; Karaoglu, S. A.; Ulusoy, E.; Baltaci, C.; Candan, F. Biological activities of three different Turkish honeys. Food Chemistry. 2007, 100, 526. [CrossRef]

${ }^{3}$ Silici, S.; Sagidic, O.; Ekici, L. Total phenolic content, antiradical, antioxidant and antimicrobial activities of Rhododendron honeys. Food Chemistry 2010, 121, 238. [CrossRef]

${ }^{4}$ Khalil, M. I.; Alam, N.; Moniruzzaman, M.; Sulaiman, S. A.; Gan, S. H. Phenolic acid composition and antioxidant properties of Malaysian Honeys. Journal of Food Science 2011, 76, 921. [CrossRef] [PubMed]

${ }^{5}$ Brudzynski, K.; Kim, L. Storage-induced chemical changes in active components of honey de-regulate its antibacterial activity. Food Chemistry 2011, 126, 1155. [CrossRef]
${ }^{6}$ Baroni, M. V., Nores, M. L., Díaz, M.D. P., Chiabrando, G. A., Fassano, J. P., Costa, C., et al. Determination of volatile organic compound patterns characteristics of five unifloral honeys by solid-phase microextraction - Gas chromatography - mass spectrometry coupled to chemometrics. Journal of Agricultural and Food Chemistry 2006, 54, 7235. [CrossRef] [PubMed]

${ }^{7}$ Pyrzynska, K.; Biesaga, M. Analysis of phenolic acids and flavonoids in honey. Trends in Analytical Chemistry 2009, 28, 893. [CrossRef]

${ }^{8}$ Viuda-Martos, M.; Ruiz-Navajas, Y.; J. Fernandez-Lopez, J.; Perez-Alvarez, J.A. Functional properties of honey, propolis, and royal jelly. Journal of Food Science 2008, 73, R117. [CrossRef] [PubMed]

${ }^{9}$ Alvarez-Suarez, J. M., Tulipani, S.; Romandini, S.; Bertoli, E.; Battino, M. Contribution of honey in nutrition and human health: A review. Mediterranean Journal of Nutrition and Metabolism 2010, 3, 15. [CrossRef]

${ }^{10}$ Bogdanov, S.; Jurendic, T.; Sieber, R. Honey for nutrition and health: A review. American Journal of the College of Nutrition 2008, 27, 677. [CrossRef]

${ }^{11}$ Zalibera, M.; Stasko, A.; Slebodova, A.; Jancovicova, V.; Cermakova, T.; Brezova, V. Antioxidant and radical-scavenging activities of Slovak honeys - An electron paramagnetic resonance study. Food Chemistry 2008, 110, 512. [CrossRef]

12 Ulusoy. E.; Kolayli, S.; Sarikaya, A. O. Antioxidant and antimicrobial activity of different floral origin honeys from Turkiye. Journal of Food Biochemistry 2010, 34, 321. [CrossRef]

${ }^{13}$ Othman, N. H. Honey and Cancer: Sustainable inverse relationship particularly for developing nations - A Review. EvidenceBased Complementary and Alternative Medicine 2012, ID 410406. [CrossRef]

${ }^{14}$ Erejuwa, O. O.; Sulaiman, S. A.; Wahab, M. S. A Effects of Honey and Its Mechanisms of Action on the Development and Progression of Cancer. Molecules 2014, 19, 2497. [CrossRef] 
${ }^{15}$ Erejuwa, O. O.; Sulaiman, S. A.; Wahab, M. S. A. Honey: A Novel Antioxidant. Molecules 2012, 17, 4400. [CrossRef] [PubMed]

${ }^{16}$ Castro-Vázquez, L.; Díaz-Maroto, M. C.; De Torres, C.; Pérez-Coello, M..S. Effect of geographical origin on the chemical and sensory characteristics of chestnut honeys. Food Research International 2010, 43, 2335. [CrossRef]

17 Ozcan, M.; Arslan, D.; Ali Ceylan, D. Effect of inverted saccharose on some properties of honey. Food Chemistry 2006, 99, 24. [CrossRef]

${ }^{18}$ Gheldof, N.; Wang, X. H.; Engeseth, N. J. Identification and quantification of antioxidant components of honeys from various floral sources. Journal of Agricultural and Food Chemistry 2002, 50, 5870. [CrossRef] [PubMed]

${ }^{19}$ Aljadi, A. M.; Kamaruddin, M. Y. Evaluation of the phenolic contents and antioxidant capacities of two Malaysian floral honeys. Food Chemistry 2004, 85, 513. [CrossRef]

${ }^{20}$ Sant'Ana, L. D.; Ferreira, A. B.; Lorenzon, M. C. A.; Berbara, R. L. L.; Castro, R. N. Correlation of total phenolic and flavonoid contents of Brazilian honeys with colour and antioxidant capacity. International Journal of Food Properties 2014, 17, 65. [CrossRef]

21 dos Santos, J. S.; Dos Santos, N. S.; dos Santos, M. L. P.; dos Santos, S. N.; Lacerda, J. J. D. J. Honey classification from semi-arid, Atlantic and transitional forest zones in Bahia, Brazil. Journal of the Brazilian Chemical Society 2008, 19, 502. [CrossRef]

22 Gallego-Picó, A.; Garcinuño-Martínez, R. M.; Fernández-Hernando, P. Honey authenticity and traceability. Comprehensive Analytical Chemistry 2013, 60, 511. [CrossRef]

${ }^{23}$ Bro, L. L. R.; Zekovic, I.; Dramicanin, T.; Dramicanin. M. D. Fluorescence spectroscopy coupled with PARAFAC and PLS DA for characterization and classification of honey. Food Chemistry 2015, 175, 284. [CrossRef] [PubMed]
${ }^{24}$ Aliferis, K. A.; Tarantilis, P.A.; Harizanis, P. C.; Alissandrakis, E. Botanical discrimination and classification of honey samples applying gas chromatography/mass spectrometry fingerprinting of headspace volatile compounds. Food Chemistry 2010, 121, 856. [CrossRef]

${ }^{25}$ Ribeiro, R. O. R.; Mársico, E. T.; Carneiro, C. S.; Monteiro, M. L. G.; Conte Júnior, C. A.; Mano, S.; de Jesus, E. F. O. LWT - Food Science and Technology 2014, 55, 90. [CrossRef]

${ }^{26}$ Herrero Latorre, C.; Peña Crecente, R. M.; García Martín, S.; Barciela García, J. A fast chemometric procedure based on NIR data for authentication of honey with protected geographical indication. Food Chemistry 2013, 141, 3559. [CrossRef] [PubMed]

${ }^{27}$ Arvanitoyannis, I. S.; Chalhoub C.; Gotsiou P.; Lydakis-Simantiris N.; Kefalas, P. Novel quality control methods in conjunction with chemometrics (multivariate analysis) for detecting honey authenticity. Critical Reviews in Food Science Nutrition 2005, 45, 193. [CrossRef]

${ }^{28}$ Baltrusaityte, V.; Venskutonis, P. R.; Ceksteryte, V. Radical scavenging activity of different floral origin honey and beebread phenolic extracts. Food Chemistry 2007, 101, 502. [CrossRef]

${ }^{29}$ Gheldof, N.; Engeseth, N. J. Antioxidant capacity of honeys from various floral sources based on the determination of oxygen radical absorbance capacity and inhibition of in vitro lipoprotein oxidation in human serum samples. Journal of Agricultural and Food Chemistry 2002, 50, 3050. [CrossRef] [PubMed]

${ }^{30}$ Estevinho, L. M.; Feas, X.; Seijas, J. A. Pilar, Vazquez-tato, M.; Organic honey from TrasOs-Montes region (Portugal): chemical, palynological, microbiological and bioactive compounds characterization. Research Support, Non-U.S. Gov't. Food and Chemistry Toxicology 2012, 50, 258. [CrossRef] [PubMed]

${ }^{31}$ Escuredo, O.; Silva, L. R.; Valentão, P.; Seijo, M. C.; Andrade, P. B. Assessing Rubus 
honey value: Pollen and phenolic compounds content and antibacterial capacity. Food Chemistry 2012, 130, 671. [CrossRef]

${ }^{32}$ Tenore, G. C.; Ritieni, A.; Campiglia, P. Novellino, E. Nutraceutical potential of monofloral honeys produced by the Sicilian black honeybees (Apis mellifera ssp. sicula). Food and Chemistry Toxicology 2012, 50 , 1955. [CrossRef] [PubMed]

${ }^{33}$ Alvarez-Suarez, J. M.; Giampieri, F. González-Paramás, A. M.; Damiani, E.; Astolfi, P.; Martinez-Sanchez, G.; Battino, M.; Phenolics from monofloral honeys protect human erythrocyte membranes against oxidative damage. Food and Chemistry Toxicology 2012, 50, 1508. [CrossRef] [PubMed]

${ }^{34}$ Silva, R. A.; Maia, G. A.; Sousa, P. H. M.; Costa, J. M. C. Composição e propriedades terapêuticas do mel de abelha. Alimentos $e$ Nutrição 2006, 17, 113. [link]

${ }^{35}$ Alvarez-Suarez, J. M.; Gonzalez-Paramas, A. M.; Santos-Buelga, C.; Battino, M. Antioxidant characterization of native monofloral Cuban honeys. [Research Support, Non-U.S. Gov't]. Journal of Agricultural and Food Chemistry 2010, 58, 9817. [CrossRef] [PubMed]

${ }^{36}$ Alves, A.; Ramos, A.; Gonçalves, M. M.; Bernardo, M.; Mendes, B. Antioxidant activity, quality parameters and mineral content of Portuguese monofloral honeys. Journal Food Composition Analysis 2013, 30 , 130. [CrossRef]

${ }^{37}$ Alvarez-Suarez, J. M.; Tulipani, S.; Díaz, D.; Estevez, Y.; Romandini, S. Giampieri, F.; Battino, M.; Antioxidant and antimicrobial capacity of several monofloral Cuban honeys and their correlation with color, polyphenol content and other chemical compounds. Food and Chemistry Toxicology 2010, 48, 2490. [CrossRef] [PubMed]

${ }^{38}$ Alvarez-Suarez, J. M.; Tulipani, S.; Romandini, S.; Vidal, A.; Battino, M. Methodological aspects about determination of phenolic compounds and in vitro evaluation of antioxidant capacity in the honey: a review. Current Analytical Chemistry 2009, 5, 293. [CrossRef]

${ }^{39}$ Cimpoiu, C.; Hosu, A.; Miclaus, V.; Puscas, A. Determination of the floral origin of some Romanian honeys on the basis of physical and biochemical properties. Spectrochimica Acta Part A: Molecular and Biomolecular Spectroscopy 2013, 100, 149. [CrossRef] [PubMed]

${ }^{40}$ Bendini, J. N.; Souza, D. C. Caracterização físico-química do mel de abelhas proveniente da florada do cajueiro. Ciência Rural 2008, 38, 565. [CrossRef]

${ }^{41}$ IBGE - Instituto Brasileiro de Geografia E Estatística. Produção Pecuária Municipal, disponível em: <http://www.ibge.gov.br>. Acessado em: 01 Agosto 2011.

${ }^{42}$ Almeida, A. M. M.; Flora visitada por Apis melífera L. em Ribeira do Pombal, Bahia. Salvador: EBDA 2007, 30. [link]

${ }^{43} \mathrm{SEI}$ - Superintendência de Estudos Econômicos e Sociais da Bahia, Estatísticas dos Municípios Baianos Território de Identidade Semiárido Nordeste II, 2011, 25. [Link]

${ }^{44}$ Louveaux, J.; Maurizio, A.; Vorwohl, G. Methods of melissopalynology. Bee World 1978, 59, 4, 139. [Link]

${ }^{45}$ Iwama, S.; Melhem, T. S. The pollen spectrum of the honey of Tetragonisca angustula angustula Latrelle (Apidae, Meliponinae). Apidologie 1979, 10, 275. [CrossRef]

${ }^{46}$ Erdtman, G.; Pollen morphology and plant taxonomy-Angiosperms, Almqvist \& Wiksell: Stockholm, 1952.

${ }^{47}$ Erdtman, G. The acetolysis method. A revised description. Svensk Botanisk Tidskrift 1960, 54, 561.

${ }^{48}$ Nilsson, S. Praglowski, J.; Erdtman's handbook of palynology, 2a. ed., Munksgaard, 1992.

${ }^{49}$ AOAC, In: K. Helrich (Ed.), Official methods of analysis, $15^{\text {th }}$ ed., Arlington. VA. USA: Association of Official Analytical Chemists 1990. [Link] 
50 Brasil. Ministério da Agricultura, Pecuária e Abastecimento. Instrução Normativa no 11. Regulamento Técnico de Identidade e Qualidade do Mel. Diário Oficial da República Federativa do Brasil, seção 1, Brasília, 23/10/2000. 2000, 20, 16-17. [Link]

${ }^{51}$ CAC. Codex Alimentarius Commision. Official methods of analysis 1990. V. 3, supl. 2.

52 Tosi, E.; Martinet, R.; Ortega, M.; Lucero, H.; Ré, E. Honey diastase activity modified by heating. Food Chemistry 2008, 106, 883. [CrossRef]

53 Cicco, N.; Lanorte, M. T.; Paraggio, M.; Viggiano, M.; Lattanzio, V. A reproducible, 800 rapid and inexpensive Folin-Ciocalteu micro-method in determining phenolics of 801 plant methanol extracts. Microchemical Journal 2009, 91, 107. [CrossRef]

54 Sânchez-Moreno, C.; Larrauri, J.; SauraCalixto, F. Free radical scavenging capacity and inhibition of lipid oxidation of wines, grape juices and related polyphenolic constituents. Food Research International 1999, 32, 407. [CrossRef]

${ }^{55}$ Rufino, M. S. M.; Fernandes, F. A. N.; Alves, R. E.; Brito, E. S. Free radical-scavenging behaviour of some north-east Brazilian fruits in a DPPH $^{\bullet}$ system. Food Chemistry 2009, 114, 693. [CrossRef]

56 Apak, R.; Güçlü, K.; Özyürek, M.; Karademir, S. E. Novel total antioxidant capacity index for dietary polyphenols and vitamins $C$ and $E$, using their cupric ion reducing capability in the presence of neocuproine: CUPRAC method. Journal of Agricultural and Food Chemistry. 2004, 52, 7970. [CrossRef] [PubMed]

57 SAEG - Sistema para Análises Estatísticas, Versão 9.1: Fundação Arthur Bernardes - UFV 2007. [Link]

${ }^{58}$ Barth, O. M. Melissopalynology in Brazil: a review of pollen analysis of honeys, propolis and pollen loads of bees. Scientia Agricola 2004, 61, 342. [CrossRef]
${ }^{59}$ Finola, M. S.; Lasagno, M. C.; Marioli, J. M.; Microbiological and chemical characterization of honeys from central Argentina. Food Chemistry 2007, 100, 1649. [CrossRef]

${ }^{60}$ Feas, X.; Pires, J.; Iglesias, A.; Estevinho, M. L. Characterization of artisanal honey produced on the Northwest of Portugal by melissopalynological and physico-chemical data. Food and Chemistry Toxicology 2010, 48, 3462. [CrossRef] [PubMed]

${ }^{61}$ Sodré, G. S.; Marchini, L. C.; Moreti, A. C. C. C.; Otsuk, I. P.; Carvalho, C. A. L. Physicochemical characteristics of honey produced by Apis mellifera in the Picos region, state of Piauí, Brazil. Revista Brasileira de Zootecnia. 2011, 1837. [CrossRef]

62 Silva, C. L.; Queiroz, A. J. M.; Figueiredo, R. M. F. Caracterização físico-química de méis produzidos no Estado do Piauí para diferentes floradas. Revista Brasileira de Engenharia Agrícola e Ambiental 2004, 8, 260. [CrossRef]

${ }^{63}$ Vela, L; de Lorenzo, C.; Perez, R. A. Antioxidant capacity of Spanish honeys and its correlation with polyphenol content and other physicochemical properties. Journal of the Science of Food and Agriculture 2007, 87, 1069. [CrossRef]

64 Khalil, I.; Moniruzzaman, M.; Boukraâ, L.; Benhanifia, M.; Islam, A.; Islam, N.; Sulaiman, S. A. Physicochemical and antioxidant properties of Algerian honey. Molecules (Basel, Switzerland) 2012, 17, 11199. [CrossRef] [PubMed]

${ }^{65}$ Belitz, H. D.; Grosch. W.; Food Chemistry Berlin, New York: Springer, 1999. [CrossRef]

${ }^{66}$ Khalil, M. I.; Sulaiman, S. A.; Gan, S. H. High 5-hydroxymethylfurfural concentrations are found in Malaysian honey samples stored for more than one year. Food and Chemistry Toxicology 2010, 48, 2388. [CrossRef] [PubMed]

${ }^{67}$ Barhate, R. S.; Subramanian, R.; Nandini, K. E.; Umesh Hebbar, H. Processing of honey using polymeric microfiltration and 
ultrafiltration membranes. Journal of Food Engineering 2003, 60, 49. [CrossRef]

${ }^{68}$ Kahraman, T.; Buyukunal, S. K.; Vural, A.; Altunatmaz, S. S. Physico-chemical properties in honey from different regions of Turkey. Food Chemistry 2010, 123, 41. [CrossRef]

${ }^{69}$ Gomes, S.; Dias, L. G.; Moreira, L. L.; Rodrigues, P.; Estevinho, L. Physicochemical, microbiological and antimicrobial properties of commercial honeys from Portugal. Food and Chemistry Toxicology 2010, 48, 544. [CrossRef] [PubMed]

${ }^{70}$ Wang, J.; LI Q. X. In Advances in Food and Nutrition Research; L. T. Steve, ed.; vol 62, 2011, 89-137. [CrossRef] [PubMed]

${ }^{71}$ Mohamed, M.; Sirajudeen, S. N. K.; Swamy, M.; Yaacob, S. N.; Sulaiman. A. S. Studies on the antioxidant properties of Tualang honey of Malaysia. African Journal of Traditional Complementary and Alternative Medicine 2010, 7, 59. [link]

${ }^{72}$ Lacerda, J. J. J.; Santos, J. S.; Santos S. A. Rodrigues, G. B.; Santos, M. L. P.; Influência das características físico-químicas e composição elementar nas cores de méis produzidos por Apis mellifera no sudoeste da Bahia utilizando análise multivariada. Química Nova 2010, 33, 1022. [CrossRef]

${ }^{73}$ Gonzalez-Miret, M.L.; Terrab, A.; Hernanz, D.; Fernandez-Recamales, M.A.; Heredia, F.J. Multivariate correlation between color and mineral composition of honeys and by their botanical origin. Journal of Agricultural and Food Chemistry 2005, 53, 2574.

${ }^{74}$ Al, M. L.; Daniel, D.; Moise, A.; Bobis, O.; Laslo, L.; Bogdanov, S. Physico-chemical and bioactive properties of different floral origin honeys from Romania. Food Chemistry 2009, 112, 863. [CrossRef]

${ }^{75}$ Lianda, R. L. P.; Sant'ana, L. D. O.; Echevarria, A.; Castro, R. N. Antioxidant activity and phenolic composition of Brazilian Honeys and their extracts. Journal of the Brazilian Chemical Society 2012, 23, 618. [link]

${ }^{76}$ Sant'ana, L. D.; Sousa, J. P. L. M.; Salgueiro, F. B.; Lorenzon, M. C. A.; Castro, R. N.;
Characterization of monofloral honeys with multivariate analysis of their chemical profile and antioxidant activity. Journal of Food Science 2012, 77, 135. [CrossRef] [PubMed]

77 Pontis, J. A.; da Costa, L. A. M. A.; da Silva, S. J. R.; Flach, A. Color, phenolic and flavonoid content, and antioxidant activity of honey from Roraima. Brazil Food Science and Technology 2014, 34, 69. [CrossRef]

${ }^{78}$ Buratti, S.; Benedetti, S.; Cosio, M. S. Evaluation of the antioxidant power of honey, propolis and royal jelly by amperometric flow injection analysis. Talanta 2007, 7, 1387. [CrossRef] [PubMed]

${ }^{79}$ Perna, A.; Intaglietta, I.; Simonetti, A.; Gambacorta, E. A comparative study on phenolic profile, vitamin $\mathrm{C}$ content and antioxidant activity of Italian honeys of different botanical origin. International Journal of Food Science and Technology 2013, 48, 1899. [CrossRef]

${ }^{80}$ Petretto, G. L.; Cossu, M.; Alamanni, M. C. Phenolic content, antioxidant and physicochemical properties of Sardinian monofloral honeys. International Journal of Food Science and Technology 2015, 50, 482. [CrossRef]

${ }^{81}$ Giorgi, A.; Madeo, M.; Baumgartner, J.; Lozzia, G. C. The Relationships between Phenolic Content, Pollen Diversity, Physicochemical Information and Radical Scavenging Activity in Honey. Molecules 2011, 16, 336. [CrossRef] [PubMed]

82 Pichichero, E.; Canuti. L.; Canini A. Characterisation of the phenolic and flavonoid fractions and antioxidant power of Italian honeys of different botanical origin. Journal of the Science of Food and Agriculture 2009, 89, 609. [CrossRef]

${ }^{83}$ Beretta, G.; Paola, G.; Ferrero, M.; Orioli, M.; Facino, R. M. Standardization of antioxidant properties of honey by $a$ combination of spectrophotometric/fluorimetric assays and chemometrics. Analytica Chimica Acta 2005, 533, 185. [CrossRef]

${ }^{84}$ Meda, A.; Lamien, C. E.; Romito, M.; Millogo, J.; Nacoulma, O. G. Determination of the total phenolic, flavonoid and proline 
contents in Burkina Fasan honey, as well as their radical scavenging activity. Food Chemistry 2005, 91, 571. [CrossRef]

${ }^{85}$ Bertoncelj, J.; Dobersek, U.; Jamnik, M.; Golob, T. Evaluation of the phenolic content, antioxidant activity and colour of Slovenian honey. Food Chemistry 2007, 105, 822. [CrossRef]

${ }^{86}$ Kishore, R. K.; Halim, A. S.; Syazana, M. S. N.; Sirajudeen, K. N. S. Tualang honey has higher phenolic content and greater radical scavenging activity compared with other honey sources. Nutrition Research 2011, 31, 322. [CrossRef] [PubMed]

87 Wilczynska, A. Effect of filtration on colour, antioxidant activity and total phenolics of honey. LWT - Food Science and. Thecnology. 2014, 57, 767. [CrossRef]

${ }^{88}$ Kus P. M.; Congiu, F.; Teper, D.; Sroka, Z.; Jerkovi, I., Tuberoso, G. I. T. Antioxidant activity, color characteristics, total phenol content and general HPLC fingerprints of six Polish unifloral honey types. LWT - Food Science and Technology 2014, 55, 124. [CrossRef]

${ }^{89}$ Isla, M. I.; Craig, A., Ordoñez, R.; Catiana Zampini, C.; Jorge Sayago, J.; Bedascarrasbure, E.; Alvarez, A.; Salomón, V.; Luis Maldonado, L. Physico chemical and bioactive properties of honeys from Northwestern Argentina. LWT - Food Science and Technology 2011, 44, 1922. [CrossRef]

${ }^{90}$ Ferreira, I. C. F. R.; Aires, E.; Barreira, J. C. M.; Estevinho, L. M. Antioxidant activity of Portuguese honey samples: Different contributions of the entire honey and phenolic extract. Food Chemistry 2009, 114, 1438. [CrossRef]

91 Aazza, S.; Lyoussi, B.; Antunes, D.; Miguel, M. G. Physicochemical characterization and antioxidant activity of commercial Portuguese honeys. Journal of Food Science 2013, 78, C1159. [CrossRef] [PubMed]

92 Noor, N.; Sarfraz, R. A.; Ali, S.; Shahid, M. Antitumour and antioxidant potential of some selected Pakistini honeys. Food
Chemistry 2014, 143, 362. [CrossRef] [PubMed].

${ }^{93}$ Gasic, U.; Keckes, S.; Dabi, D.; Trifkovic, J.; Milojkovic-Opsenica, D.; Natic, M.; Tesic, Z. Phenolic profile and antioxidant activity of Serbian polyfloral honeys. Food Chemistry 2014, 145, 599. [CrossRef] [PubMed]

94 Gorjanovic, S. Z.; Alvarez-Suarez, J. M.; Novakovic, M. M.; Pastor, F. T.; Pezo, L.; Battino, M.; Comparative analysis of antioxidant activity of honey of different floral sources using recently developed polarographic and various spectrophotometric assays. Journal of Food Composition and Analysis, 2013, 30, 13. [CrossRef]

${ }^{95}$ Vit, P.; Rodrígues-Malaver, A.; Roubik, D. W.; Moreno, E.; Souza, B. A.; Sanchos, M. T.; Fernández-Muiños, M.; Almeida-Anacleto, D.; Marchini, L. C.; Gil, F.; González, C.; Aguilera, G.; Nieves, B. Expanded parameters to assess the quality of honey from Venezuelan bees (Apis mellifera). Journal of ApiProduct and ApiMedical Science 2009, 1, 72. [CrossRef]

${ }^{96}$ Saxena, S.; Gautam, S.; Sharma, A. Physical, biochemical and antioxidant properties of some Indian honeys. Food Chemistry 2010, 118, 391. [CrossRef]

97 Lachman, J.; Orsak, M.; Hejtmankova, L.; Kovarova. E. Evaluation of antioxidant activity and total phenolics of selected Czech honeys. LWT - Food Science and Technology, 2010, 43, 52. [CrossRef]

${ }^{98}$ Moreti, A. C. C. C.; Sodré, G. S.; Marchini, L. C.; Otsuk, I. P. Características físico-químicas de amostras de méis de Apis mellifera L. do estado do Ceará, Brasil. Ciência $e$ Agrotecnologia 2009, 33, 191. [CrossRef]

${ }^{99}$ Frankel, S.; Robinson, G. E.; Berenbaum, M. R. Antioxidant content and correlated characteristics of 14 monofloral honeys. Journal of Apicultural Research 1998, 37, 27. [link]

100 Pérez, R. A.; Iglesias, M. T. Pueyo, E.; Gonzalez, M.; de Lorenzo, C. Amino acid composition and antioxidant capacity of Spanish honeys. Journal of Agricultural and 
Food Chemistry 2007, 55, 360. [CrossRef] [PubMed].

${ }^{101}$ Schramm, D. D.; Karim, M.; Schrader, H. R.; Holt, R. R.; Cardetti, M.; Keen, C. L. Honey with high levels of antioxidants can provide protection to healthy human subjects. Journal of Agricultural and Food Chemistry 2003, 51, 1732. [CrossRef] [PubMed]. 